\title{
United Notation 2030 Agenda for Sustainable Development Goals: Appraisal and Prospects
}

Mohammed M. Saleh

\author{
Dr., Assistant Professor, International Development Department, Prince Al-Hussein Bin Abdullah II School of
} International Studies, The University of Jordan

\begin{abstract}
United Nations adopted in 2015 seventeen Sustainable Development Goals to be achieved in 2030.The main goals are: ending poverty, ending hunger, achieving equity in heath, education, water treatment and sanitation, full and productive employment for all, sustainable economic growth, sustainable consumption and production pattern, combat climate change and other environmental goals. There are many constraints encountering the achievements of these goal.These constraints are basically financial and political. This paper emphasizes that these goals cannot be achieved without large scale of international financial support in term of grants and easy term loans. In addition, UN has to play its role in preserving international peace and security which are the basic elements in sustainable development. Time frame for achieving sustainable development goals should be extended, probably, to the mid of this century.
\end{abstract}

Keywords: Sustainable Development Goals, Economic, Financial, Political

\section{Introduction}

In 25th of September 2015, General Assembly of United Nation adopted A/Res/70/1 Resolution named Transforming Our World: The 2030 Agenda for Sustainable Development"This Resolution contained 17 goals of Sustainable Development to be achieved in 2030. Before we go to describe and evaluate them it is important to give brief outline about the concept of sustainable development

\section{The Emerg of Sustainable Development Concept}

Sustainability is the term chosen to bridge the gulf between development and environment. Originally it came from forest, fisheries and ground water which dealt with quantities such as " maximum sustainable cut, maximum sustainable yield, maximum sustainable pumping rate."[1]

The concept of sustainable development found in the report "Our Common Future"of the World Commission on Environment and Development (WCED). This report was done by the UN General Assembly in 1983 and completed in 1987. The report defined Sustainable Development as a "development that meets the needs of the present without comprising the ability of future generations to meet their own needs."[ 2]

The report stated that "... part of the environmental problem is that some of (rich) nations are consuming too much, while at the other end of the continuum, environmental problems are caused by people living in poverty who use the environment unsustainably because their own survival is otherwise at stake."[3]

Sustainable development is a dynamic process of change in which the exploitation of resources, the direction of investment, the orientation of technological and institutional change with future as well as present needs.[4]

According to the Commission report sustainable development in the final analysis must rest on political well of the governments as a critical economic, environmental and social decision are made.[5]

The rapid industrialization and economic development took place after the Second World War in the west caused negative socio- disparities and environmental consequences. Wide variation in standard of living, education, health, water treatment and sanitation, unemployment between North and South are are main features of these consequences.Poverty and around 800 million people facing hunger are more acute in the South which require large scale international humanitarian support. Exhausting natural resources basically nonrenewable ones, degradation and pollution of air and soil and increasing atmosphere temperatures are the main part of environmental problems. 
Eliminate poverty and hunger are the first priority for UN Sustainable Development."Within the sustainable development, the Commission recommended that 'overriding priority' should be given to the essential need of the world poor"[ 6$]$

\section{Our World Today as Described in the UN Adenda}

The UN assembly Resolution A/Res/70/1 summarized the current our world situation as follows:"

Billions of our citizens continue to live in a poverty and are denied a life of dignity. There are rising inequalities within and among countries. There are enormous disparities of opportunity, wealth and power. Gender inequality remains a key challenge. Unemployment,particularly youth unemployment, is a major concern. Global health threats, more frequent and intense natural disasters, spiraling conflict, violent extremism, terrorism and related humanitarian crisis and forced displacement of people threaten to reserve much of the development progress made in recent decades. Natural resource depletion and adverse impact of environmental degradation, including desertification, drought, land degradation, freshwater scarcity and loss of biodiversity, add to and exacerbate the list of challenges which humanity faces. Climate change is one of greatest challenges... Increases in global temperature, sea level rise, ocean acidification and other climate change impact are seriously affecting coastal areas and low-lying coastal countries, including many least developed countries and small island developing states. The survival of many societies, and of the biological support systems of the planet"[7]

\section{UN Goals of Sustainable Development For 2030}

The assembly of UN adopted the following goals to be achieved in 2030 as indicated in the Resolution A/Res/70/1. These goals are:"

1-Ending poverty in all its forms everywhere, 2-End hunger, achieve food security, improve nutrition and achieve agriculture sustainable development, 3-Ensure health lives and promote well-being for all at all ages, 4-Ensure inclusive and equitable quality education...,5-Achieve gender equality and empower all women and girls, 6- Ensure availability and sustainable management of water and sanitation, 7-Ensure access to affordable, reliable, sustainable and modern energy for all, 8Promote sustained, inclusive and sustainable economic growth, full and productive employment and decent work for all, 9Build resilient infrastructure, promote inclusive and sustainable industrialization and foster innovation, 10-Reduce inequality within and among countries, 11- Make cities and human settlements inclusive, safe, resilient and sustainable, 12- Ensure sustainable consumption and production pattern, 13- Take urgent action to combat climate change and its impacts, 14Conserve and sustainably use the oceans, seas and marine resources for sustainable development, 15- Protect, restore and promote sustainable use of terrestrial ecosystems, sustainably mange forest..., 16- Promote peaceful and' inclusive societies for sustainable development, provide access to justice for all..., 17-Strengthen the means of implementation and Revitalize the Global Partnership for Sustainable Development."[8]

\section{Appraısal and Prospect of Achıeving UN Suitable Development Goals}

The sustainable development goals adopted by UN are highly optimistic, if some of them are utopias ,to be achieved in 2030. Without overcoming many constraints and obstacles, these goals will stay just as slogans. The main constraints and obstacles are:

\section{1- Economic and Fınancial Constraınts}

\section{Providing Basic Human Needs}

"Ending poverty, End hunger, Ensure health lives, Ensure inclusive and equitable quality education, and Ensure availability and sustainable management of water and sanitation". These goals are essential human need and human rights. Besides, without providing theses services as a basic needs, economic growth is not possible in a societies facing hunger, illiteracy is high, unacceptable health services, shortage of potable water, high unemployment and poverty.

Within the constraint of unavailability of financial resources in most developing and underdeveloped countries, achieving these goals are not possible without international financial help.

Food and other basic service have to be highly subsidized, at least in the transitional stage, until economic growth takes place. 
International Monetary Fund and other international financial institutions have to modify its criteria of financing. Eliminate all kinds of subsides for goods and services as conditions for providing loans to developing countries should be, postponed. Countries with limited financial resources cannot make these good and service available in subsidized prices for poor people without international financial support.

Iraqi subsidized Food Ration implemented during thirteen years of sanction, saved Iraqi's from famine. This system provides food basket in nominal prices and still running until now.Similar system is running in India covering 800 million people[9 ].This kind of program is required for poor people.

\section{Economic Growth and Raising Standard of Living}

"Promote sustained, inclusive and sustainable economic growth, full and productive employment and decent work for all, Ensure access to affordable reliable, sustainable and modern energy for all,Build resilient infrastructure, promote inclusive and sustainable industrialization and foster innovation. Make cities Ensure sustainable consumption and production pattern. Make cities and human settlements inclusive, safe, resilient and sustainable." These goals cannot be achieved in developing and underdeveloped countries, without international financial loans in acceptable terms.Enhancing foreign investment including helping Governments to creat healthy environment for foreign investment.

\section{2- Political Constraints}

\section{Ending Imposing All Forms of Sanctions by United Nations}

Since the formation of United Nations, Security Council imposed several comprehensive and partial sanctions on many countries to achieve certain political objectives set in each resolution. Comprehensive Sanction imposed on South Rhodesia, Iraq , Haiti and former Yugoslavia.The harshest sanction was imposed on Iraq for thirteen years. The object of 661 (1990)Sanction Resolution was to force Iraq to withdraw from Kuwait. This resolution prevented Iraq from exporting and importing any commodity including food and medicine.Once Iraq withdrawn form Kuwait, Security Council adopted another resolution (687-1991)to dismantle Iraqi Mass Distortion Weapons(MDW).Sanction continued until US and Britain invaded Iraq in 2003. No MDW were found after the invasion.[10]

Thirteen years of the most pervasive sanction in the history of mankind turn rich country to the poorest as stated by American Professor Joy Gordon in her book published in 2010 named 1 Invisible War". She stated:" What I want to explore now is the question of how a human catastrophe of this magnitude came about: what policies and practices were that caused hundreds of thousands of deaths; decimated the health of several million children; destroyed a whole economy; made a shambles of

nation's education and health care system; reduced the sophisticated country, in which much of the population lived as a middle class in the First World country; to the status of Forth World countries- the poorest of the poor, such as Rwanda, Somalia and Haiti; and in a society notable for its scientists, engineers, and doctors, established an economy dominated by beggars, criminals, and black makers... and by undermining the infrastructure-electricity production, telecommunications, transport,, and water and sewage treatment- in an advanced industrialized society that was highly dependent on modern infrastructure."[ 11]

The only victims of sanctions are people calling for ending imposing comprehensive sanction[12 ]

Therefore, sanctions are working against the sustainable development goals mentioned above.

If there is an urgent need to impose sanction by Security Council, It should not exceed military weapons and MDW. Any restrictions on importing civilian commodities, civilian projects and exporting commodities should be avoided.

\section{Declining the Role of UN in Maintaining Regional and International Peace and Security}

The failure of UN to prevent invading Iraq in 2003 destabilized the whole region. The consequent interventions in Syria, Yaman and Libya undermined the potential of these countries to keep pace with their previous policies and practices in socio- economic development. Despite lifting sanction in 2003, Iraq still suffering from destabilization. Terrorism absorbed the potential of development and large scale of displaced people still main problem in Iraq.Syria was considered the only Arab country which had self sufficiency in food production is now importing food.More than have of Syrian population are refuges in Jordan, Lebanon, Turkey ,Germany,Austria and other countries. Jordan, a country of limited resources hosted 
mor than 1.5 million Syrian refugees. One third of Jordan population are refugees without sufficient international support[13]. Jordan is facing economic difficulties due to consequences of instability in the region as a result of invading Iraq . These are jus few example, as apart of the whole world, which hinder any effort to change the world to a situation desired in the UN 2030 Agenda for Sustainable Development.

Consequently, huge amount of financial and human resource are required not to attain UN Agenda of Sustainable Development for 2030, but at least to go back to situation before 2003 in these Iraq, Syria, Yemen and Libya .

The current international political situation is not in the direction of stability, in contrary its going toward more escalation basically with Iran and North Korea.

Unless UN able to play its role in preserving international and regional peace and security and to prevent bilateral interventions, sustainable development goals cannot be achieved as planned by UN. However, UN should give priority to stable countries.

\section{Political Well of Governments}

It is very important that the governments of developing and underdeveloped counties have to believe in and support the implementation of the Agenda of Sustainable Development when international financial and economic support become available for their countries. Due to high corruption behavior of large number of these countries , and to secure that any financial and economic support goes directly to the beneficiaries, that support should not be given on cash basis, but should be provided in term of goods and building projects.

\section{2- Tıme Constraınts}

Assuming that economic and financial resources available, and the designated countries remain stable, is impossible that the goals of sustainable development can be achieved, partially or completely, during the coming thirteen years from now.So, extend time for achieving these goals from 2030 to another year, probably to the mid of this century is required.

\section{Conclusion}

Large scale of international financial support is required to attain sustainable development goals adopted in 2015 by the Assembly of United Nations. Instability in many part of the world basically in middle east threatening these goals. Invading Iraq $\mathrm{n} 2003$ was the main factor led to destabilize the region. Without international financial support and without strong role of UN to preserve international peace and security, sustainable development goals cannot be achieved.Time span fixed for achieving these goals is limited and should be adjusted, probably, to the mid of this century.

\section{References}

[1] Rogers PP, Jalal KF, Boyd JA,( 2008), "An Introduction to Sustainable Development". Glen Educational Foundation, P.22.

[2] Elliott, Jennifer A (2013), An Introduction to Sustainable Development, Forth Edition, Routledge, P 8.

[3] Weeks, John R, ( 2012 ) An Introduction to Population ,Wadsworth, Gengage Learning, p479.

[4] Rogers p,P. Ibid. p.42

[5] Ibid.P.42.

[6] Weeks,John R. Ibid, P.479

[7] Transforming Our World:The2030 Agenda For Sustainable Development A/RES/70/1, United Nations

[8] Ibid.

[9] Saleh, Mohammad M,(2015, July)" Food Ration System Prevented Eminent Famine in Iraq During 19902003Sanction" British Journal of Humanities And Social Science" Vol.13 (2).

[10] Saleh, Mohammad M. (2016, June), Illegality of Imposing Comprehensive Sanction on Iraq:Contradiction policy of Security Council, European Scientific Journal,Special Edition. 
[11] Gordon, J, ( 2010 ) Invisible War, The United States and thelraqi Sanction, President and Fellows of Harvard College, P.87.

[12] Saleh, Mohammed M.(2015, Oct.),"Towards Abolishing Imposing Comprehensive Sanction: Sanction Damaged Iraqi Society and Food Ration System Saved it from Famine" Third International Conference on Advances in Social Science, Management and Human Behavior " Institute of Research Engineers and Doctors, USA,Proceedings.

[13] Saleh, Mohammed M (2017, April)"Influx of Refugees to Jordan Since 2003 and its impact on Sustainable Development" international Academic Conference Paris, International Academic Journal, USA. 